\title{
STUDI TERHADAP PROSES BELAJAR MENGAJAR BERBASIS MODEL PROJET BASED LEARNING PADA SISWA KELAS 1 SEKOLAH DASAR D MASA PANDEMI COVID19
}

\author{
Nizzaellatin Putri Mulyana ${ }^{1}$, Wahyu Lestari ${ }^{2}$ \\ ${ }^{1}$ Pendidikan Dasar, Pascasarjana, Universitas Negeri Semarang \\ ${ }^{2}$ Pendidikan Dasar, Pascasarjana, Universitas Negeri Semarang \\ 1npturimulyana@students.unnes.ac.id, 2wahyupyarlestari@mail.unnes.ac.id, \\ ${ }^{1} 089679398426,{ }^{2} 087839567800$
}

\begin{abstract}
The covid-19 pandemic is an obstacle to every sphere, and it causes many impacts, one of is perceived in the domain of education, where there iks a limitation in the learning system. To curb the spread of covid-19 lessons from home, as well as being done virtually, how a teacher is required to maximize the teaching process to achieve the purpose of learning. Grade 1 elementary school Al-Imam Karawang teacher use the learning models project based learning that's make one of the alternative learning models in the process of learning of the covid-19 pandemic to achieve the objectives of learning and student learning. Research aims to find out how the process of learning to teach grade 1 at elementary school Al-Imam Karawang, based on the learning model project based learning at the covid-19 pandemic. Research methode use with a description roughly qualitative, which describe both teaching learning process use project based learning models. The research subject use by grade 1 of elementary school Al-Imam Karawang. Data colletion in this study is observing,interview, and document. As a result of this study, learning process used project based learning models against elementary student at the time of the covid-19 pandemic is a good. A project based learning model is used in some subject and is able to make teaching learning process maximal and achive learning goals.
\end{abstract}

Keywords: Teaching Learning Process, Project Based Learning, Covid 19 Pandemic.

\section{ABSTRAK}

Pandemi covid-19 menjadi kendala bagi setiap kalangan, dan menyebabkan banyak dampak, salah satu dampak dirasakan pada ranah pendidikan, dimana menjadi ada keterbatasan dalam sistem pembelajaran. Untuk mengurangi penyebaran covid-19 pembelajaran dari rumah masing-masin, serta dilakukan secara virtual sudah dilaksanakan, tinggal bagaimana seorang guru dituntut untuk memaksimalkan proses belajar mengajar hingga tercapai tujuan pembelajaran. Guru sekolah dasar kelas 1 di Karawang tepatnya Sekolah Dasar Al-Imam menggunakan model pembelajaran project based learning yang menjadikan salah 
satu alternatif model pembelajaran dalam proses belajar mengajar di era pandemi covid-19 guna tercapainya tujuan pembelajaran dan hasil belajar siswa. Penelitian bertujuan untuk mengetahui bagaiamana proses belajar mengajar siswa kelas 1 Sekolah Dasar Al-Imam Karawang berbasis model pembelajaran project based learning di masa pandemi covid-19. Jenis metode penelitian digunakan deskripsi dengan pendektannya adalah kualitaif, yang mendeskripsikan proses belajar mengajar dan hasil pembelajaran berbasis model project based learning. Subjek penelitian yang digunakan siswa kelas 1 Sekolah Dasar Al-Imam Karawang. Teknik dalam pengumpulan data dalam penelitian ini dengan melakukan observasi, wawancara dan studi dokumentasi. Hasil didalam penelitian ini bahwa prorses belajar mengajar berbasis model project based learning terhadap siswa kelas 1 Sekolah Dasar Al-Imam Karawang di masa Pandemi covid-19 dikatakan baik. Model project based learning digunakan di beberapa mata pelajaran dan mampu memaksikmalkan proses belajar mengajar dan tercapainya tujuan pembelajaran dengan maksimal.

Kata Kunci: Belajar Mengajar, Project Based Learning, Pandemi Covid-19.

\section{A. Pendahuluan}

Proses belajar mengajar menjadi hal yang sangat penting di era pandemic covid-19 guna untuk mencapai tujuan pembelajaran. Sistem pendidikan yang awal mula pembelajaran dilakukan dengan pergi kesekolah, memakai seragam dan bertemu langsung dengan gurupun dihentikan. Seperti yang dkemukakan

Guru dan siswa harus beradaptasi dengan sistem pembelajaran melalui berbantuan teknologi yang kerap dijumpai dalam aplikasi di masa pandemi covid 19 ini seperti google meet, zoom, dan google class room dikemukakan oleh (Besare 2020). Pilihan penggunaan apliksai tergantung pada kebutuhan siswa serta guru dalam proses belajar mengajar

(Covid- 2020) mengemukakan proses belajar mengajar di masa ini tetap harus dilakukan secara interaktif, komunikatif dan menyenangkan yang dilakukan oleh guru dengan siswa siswa memiliki pengalaman secara langsung dalam memahami konsep. Disinilah ke profesioinalan guru diuji. Adanya pembelajaran yang bermakna dari proses belajar mengajar pengetahuan atau informasi yang didapatkan oleh siswa dapat melekat lama dalam ingatan siswa sehingga siswa dengan mudah dapat menyelesaikan masalah dalam setiap pembelajaran. Penentuan model belajar yang tepat 
merupakan

usaha

dalam

mengoptimalkan kemampuan berfikir, terutama berfikir tingkat tinggi (Untari, Rohmah, and Lestari 2018). Tentunya model pembelajaran project based learning dapat membuat siswa belajar menjadi menyenangkan dan bermakna (Lestari, Pratama, and Hidayatillah 2020).

Di tengah permasalahan ini pendidik harus berupaya sehingga tujuan pembelajaran tetap tercapa. Seorang pendidik kelas rendah yang kita ketahui siswa belum terbenukkemandiriannya guru hrus membuat proses belajar mengajar dengan optimal, dan dapat berjalan efisien serta efektif (Anon 2020) .

Dalam proses belajar mengajar hendaknya seorang guru menggunakan model pembelajaran tepat, yang membuat siswa berperan aktif dala proses belajar sehingga mampu membangkitkan motivasi belajar siswa, mengembangkan keterampilan dan pengetahuannya, mengasah siswa memecahkan suatu masalah yang pada akhirnya mencapai suatu prestasi belajar dengan maksimal (Wahyu Lestari, 2018). Sesuai dengan hasil wawancara dan observasi kepada siswa kelas 1 dan guru SD Al-Imam, perlunya inovasi model pembelajaran. Siwa merasa jenuh ketika seorang guru masih ada yang menggunakan model pembelajaran konvensional. Perlu adanya inovasi model pembelajaran agar kegiatan proses belajar mengajar dapat meningkatkan pemahaman siswa, membuat sisa lebih aktif, dan dapat mengasah kemampuan mereka dalam menyelesaikan masalah. Sehingga proses belajar mengajar berbasis project based learning yang dilakukan secara virtual dapat membuat pembelajaran lebih bermakna, meningkatkan kualitas belajar dan hasil belajar siswa. (Rojabiyah and Setiawan 2015) mengemukakan kondisi proses belajar mengajar di era pandemi covid-19 mendorong seorang pendidik menemukan model pembelajaran yang tepat. Seperti dalam penelitian ini implementasi model project based learning pada mata pelajaran Matemtika.

Tujuan untuk memahami suatu konsep ada dalam tujuan pembelajaran Matematika yang harus dikuasai dan dicapai. Berdasarkan tujuan tersebut proses pembelajaran harus menekankan pada aktivitas siswa aqar membangun pengetahuan melalui serangkaian kegiatan untuk 
Didaktik : Jurnal IImiah PGSD STKIP Subang, ISSN Cetak : 2477-5673 ISSN Online : 2614-722X Volume 07, Nomor 01, Juni 2021

menciptakan pembelajaran bermakna bagi siswa (Nugraha, Fuadah, and Amalia 2020). Model pembelajaran project based learning merupakan model pembelajaran inovatif, yang dilakukan secara kolaboratif dan berfokus pada pemecahan masalah yang berhubungan dengan kebutuhan siswa. Pembelajaran project based learning memiliki potensi besar untuk guru terhadap siswa membuat pegalaman belajar menjadi lebih menarik dan bermakna menurut (Rati, Kusmaryatni, and Rediani 2017).

Pembelajaran berbasis proyek dapat didefinisikan sebagai sebuah pembelajaran dengan aktivitas jangka panjang yang melibatkan siswa dalam merancang, membuat, dan menampilkan produk untuk mengatasi permasalahan dunia nyata. Ciri khas dari pembelajaran berbasis proyek yang membedakannya dengan model pembelajaran lainnya adalah adanya produk yang harus dibuat dan ditampilkan oleh siswa dalam pembelajaran berbasis proyek.

\section{B. Metode Penelitian}

Metode penelitian yang digunakan jenis deskriptif analisis. Dimana pengertian metode deskriptif analisis meruapakan suatu metode mendeskripsikan atau dengan memberi sebuah gambaran pada objek yang penelitian meluai sampel atau data nyata yang terkumpul dan dilakukan analisis serta merumuskan kesimpulan yang berlaku umum (Sugiyono 2016). Peneitian ini medeskripsikan proses belajar mengajar berbasis project based learning serta hasil belajar siswa kelas 1 dengan jumlah siswa 20. Siswa perempuan 10 dan laki-laki 10 . Sekolah Dasar pada masa Pandemi Covid 19 dianalisis. Teknik pengumpulan data dalam penelitian ini dilakukan wawancara, selanjutnya observasi serta dokumentasi.

Data di dalam penelitian ini di deskripsikan dengan kata lain digambarkan dalam bentuk kalimat. Instrument penelitian dalam penelitian ini adalah peneliti itu sendiri. Data peneletian berdasarkan dari dokumentasi yang berbentuk gambar dalam penelitian ini untuk mengethaui bagaimana proses belajar mengajar ketika diapangan, dan hasil belajar siswa.

Teknik pengumpulan data penelitian ini yaitu dokumentasi, observasi terstruktur dan wawancara terstruktur sebagai penguat data (Iryanti, Lestari, and Bisri 2021). 
Berdasarkan hal ini perlu adanya alterntif model pemebelajaran yang efektif diterapkan terhada siswa untuk meningkatkan kompetensi siswa dalam proses belajar dimasa pandemi Covid-19. Dampak pandemi Covid-19 yang terjadi membuat pembelajaran menjadi terhambat karena proses pembelajaran dilakukan di masingmasing rumah siswa dan menetapkan jaga jarak (Lestari et al. 2020). Pembelajaran online berbasis model pembelajaran project based learing menjadi salah satu solusi proses belajar menajar agar tetap dilakukan untuk menjawab permasalahan (Kusuma 2018).

Beberapa kelebihan model project based learning yang dikemukakan oleh Wena dalam (Lukman 2020) memaparkan yaitu (1) Dapat meningkatnya motivasi belajar siswa, mendorongnya kemampuan siswa untuk melakukan kegiatan dan siswa perlu dihargai . (2) Meningkatnya kemampuan siswa untuk memecahkan masalah, dan siswa dapat menjadi lebih aktif serta mampu memecahkan masalahmasalah yang kompleks, (3) Meningakatkan kolaborasi antar siswa. (4) Dapat meningkatkan keterampin siswa dalam mengelola dari suatu sumber. (5) Peningkatan sumber daya dalam management skill. Berdasarkan beberapa kelebihan tersebut, diharapkan model project based learning menjadi salah satu alternatif model pemebelajaran yang mampu memaksimalkan peroses belajar megajar dan hasil belajar siswa di masa pandemi covid-19.

\section{C.Hasil Penelitian dan Pembahasan}

Penelitian ini dilakukan pada siswa kelas 1 di SD Al-Muntaz Karawang. pada sisw kelas 1 berjumlah 20 siswa, yang diklasifikasikan siswa perempuan 10 dan siswa laki-kai 10 . Model pembelajaran project based learing dilakukan pada mata pelajaran Matematika mengenai bangun datar. Implementasi model pembelajaran project based learning pada materi bangun datar dilakukan dua kali pertemuan dengan hasil akhir berupa produk.

\section{Siklus 1}

Pada siklus pertama, pertemuan mengunakan zoom untuk melakukan kegiata proses belajar mengajar di era pademi covid-19. Guru memberikan informasi terkait link zoom yang didalamnya terdapat kegiatan pembelajaran ketika sehari sebelum 
proses pembelajaran dimulai. Pembelajaran melalui zoom dimulai pukul 07.00 WIB. Guru kelas 1 SD AIImam membuka kelas dengan salam, menyapa siswa, melakukan absensi dan memberikan motivasi berupa tepuk semangat bersama-sama yang diikuti oleh seluruh siswa kelas 1 yang sudah masuk pada room zoom.

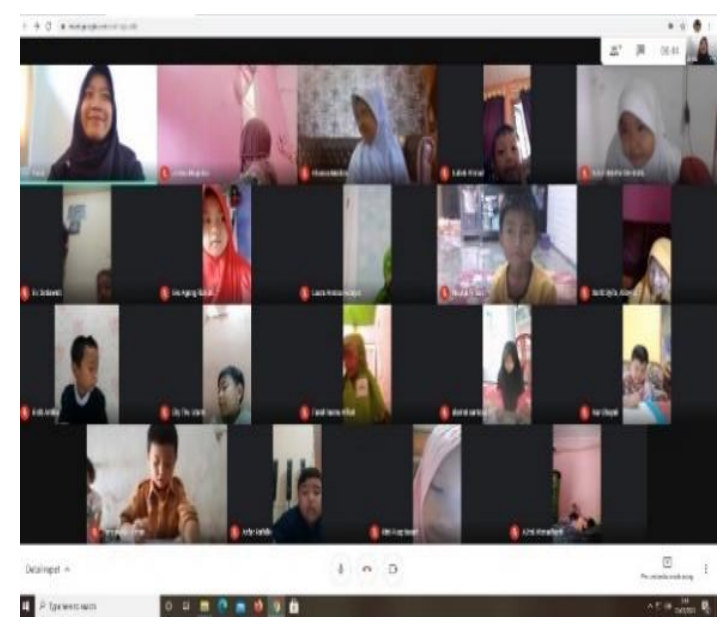

Gambar 1. Proses Belajar Mengajar ke 1

Guru menyampaikan tujuan pembelajaran hari ini dan mengaitkan pelajaran sebelumnya dalam materi di mata pelajaran Matematika yang akan dibahas. Guru mengajukan beberapa pertanyaan mengenai macam-macam bentuk bangun datar. Setelah siswa mencoba menjawab guru menjelaskan dan membahas materi berbagai bentuk jenis bangun datar dengan berbantuan media pembelajaran berbentuk konkrit yang mudah siswa temui di rumahnya dan yang biasa siswa lihat sehari. Salah medianya adalah kertas origami berbentuk segiempat, segitiga dan lingkaran. Siswa menyimak secara seksama sambil menunjukan beberpa benda yang ada di sekililing mereka dan bertanya apakah benda tersebut termasuk dari bagian bangun datar yang guru jelaskan.

Selanjutnya guru merespon beberapa pertanyaan yang diajukan oleh siswa. Tiap-tiap guru mengajukan pertanyaan da dijawab oleh siswa guru selalu mengucapkan terimakasih, begitupun siswa. Guru menerapkan

pembeiasaan mengucapakan maaf, terimakasih serat tolong. Setelah membahas materi guru mengajukan pertanyaan kepada siswa mengenai contoh bentuk segiempat, segitiga dan lingkaran yang ada disekililing mereka, kemudian siswa begitu cepat tanggap dan aktif menjawab pertanyaan yang diajukan oleh guru sehingga pembelajaran begitu interaktif. Siswa dan guru merancang proyek membuat celengan dari berbagai bentuk bangun datar yang telah dipelajari.

Guru memberikan beberapa contoh bentuk celengan dengan power point. Siswa menyampaikan 
beberapa ide kreatif mereka mengenai bentuk celengan dari jenisjenis bangun datar serta warna yang ingin mereka buat nanti. Guru dengan ramah merespon siswa. Guru dan siswa secara berkolaboratif merancang untuk pertemuan selajutnya yaitu kedua. Ada beberapa perintah guru untuk siswa yaitu, menyiapkan bahan-bahan seperti kardus, karton, gunting serta lem yang sudah dibentuk beberapa jenis bangun datar sesuai dengan bentuk celengan yang diinginkan dari ide serta kreativitas siswa.

Guru memonitor satu peratu mengenai apa yang ingin mereka berbuat, pengecekan kembali bahan dan alat yang mereka perlukan. Guru memberi pertanyaan kepada siswa dari salah satu contoh celengan yang ditampilkan, "bentuk bangun datar apa saja yang ada pada bagian celengan itu?". Siswa menjawab dengan begitu aktif sesuai denga apa yang mereka tau "ada lingkaran, "ada segitiga bu", "ada segiempat". Kemudia guru memberi reward dengan tepuk tangan atau dengan ucapan. Kemudian guru menyampaikan lembar kerja siswa yang ditampilkan dilayar untuk menjelaskan bagaimana cara pengisiannya. Ketika guru menjelaskan siswa didampingi oleh wali murid dan memberi tahu penjelasan tugas hari ini dan projek untuk besok akan di bagikan lagi didalam grup kelas yang ada dalam aplikasi wa Bersama orang tua murid. Guru memberika waktu untuk siswa bertanya mengenai tugas serta bahan-bahan yang perlu disiapkan. Beberapa siswa bertanya yang langsung dijawab oleh guru. Guru meberikan aturan pengumpulan tugas yang dikerjakan dalam waktu 10 menit setelah kegiatan pembelajaran selesai. Guru membahas Kembali apa yang mereka pelajari hari ini. Guru memberikan reward kepada para siswa, kemudian menutup serta salam.

\section{Siklus 2}

Pada siklus kedua, seperti biasa sebelum memulai proses pembelajaran guru sudah mengingatkan link zoom serta apa saja materi pembelajaran dan bahanbahan yang perlu disiapkan, kemudian tak lupa guru mengingatkan beberapa siswa yang belum mengumpulkana tugas individu mereka. Pukul 07.00 wib guru sudah masuk dalam link zoom kelas, tidak berapa lama beberapa siswapun 
Didaktik : Jurnal IImiah PGSD STKIP Subang, ISSN Cetak : 2477-5673 ISSN Online : 2614-722X Volume 07, Nomor 01, Juni 2021

masuk hingga kiranya jumlah siswa sudah mulai hadir cukup banyak guru memulai pembelajarannya. Tidak lupa guru telah mengucapkan salam, dengan kompak siswa menjawab salam.

Guru melakukan absensi pada siswa. Memberika motivasi dengan tepuk semangat pagi, yang diikuti oleh para siswa meskipun hanya virtual tapi tepuk tangan para siswa kelas 1 begitu kompak serta semangat. Tepuk semangant dilakukan sebanyak tiga kali. Kemudian guru mengaitkan materi sebelumnya dengan materi yang akan dipelajari. Guru bertanya kepada siswa apakah ada yang ingat materi pelajaran kemarin yang telah dibahas. Beberapa siswapun menjawab secara bersamaan. Guru menunjuk dan bertanya pada beberapa siswa tentang jawaban yang mereka jawab perihal materi yang sudah dibahas kemarin. Tanpa canggung siswa terlihat santai dan berani dalam menjawab.

Guru meengucapkan terimakasih kepada siswa dalam setiap pertanyaan yang diajukan. Kemudian guru membahasa materi pengelompokan bangun datar. Sebelum itu guru memerintahkan siswa untuk mentiapkan bahan yang harus disediakan. Dalam pembuatan celengan terdiri dari beberapa bangun datar yang dijadikan acuan pertanyaan serta pernyataan jawaban untuk para siswa. siswa diberi waktu 10 menit untuk menyiapkan bahan serta buku untuk menjawab pertanyaan.

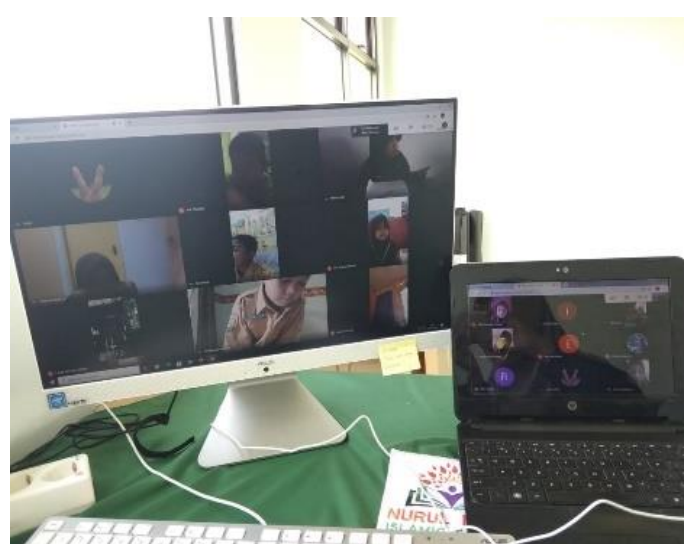

Gambar 2. Peoses Pembelajaran ke 2

Setelah semua siap guru memberikan intruksi untuk melihat bahannya dengan cara menunjukkannya kekamera siswa masing-masing. Kemudian guru memberikan aturan untuk menjawab pertanyaan yang diajukan olehnya kepada siswa. Setelah guru membacakan pertanyaannya siswa menjawab dibuku tulis masing-masin. Guru akan mengulangi setiap pertanyaan dua kali, dan siswa diberi waktu 3 menit untuk menjawab setiap pertanyanya. Diikuti terus sampai pertanayaan itu selesai. Kemudian 
setelah itu guru meminta siswa memfotokan hasil jawabannya. Siswa menyimak dengan baik apa yang guru jelaskan. Guru memberikan kesempatan untuk siswa bertanya. Siswa terlihat begitu menerka untuk memahamik sehingga tidak ada yang bertanya terkait aturan cara menjawab pertanyaan.

Guru mengajukan pertanyaan yang pertama tuliskan 2 benda yang termasuk kelompok segiempat. Soal kedua tuliskan 2 benda yang termasuk kelompok segitiga, dan yang ketiga tuliskan 2 benda yang termasuk kelompok lingkaran. Sistem dalam pengisiannya secra lisan. Siswa dengan fokus menyimak pertanyaan dari guru yang biasa diajukan sebanyak 2 kali pengulangan. Ketika menyebutkan soal yang pertama salah satu siswa laki-laki bertanya tentang soal yang guru jelaskan, karena siswa tersebut memiliki kendala jaringan.Guru bekata pada siswa tersebut bahwa beliau akan mengirimkan pertanyaannya juga di group aplikasi wa sehingga setiap anak yang memiliki kendala jaringan bisa melihat digroup yang dibantu oleh wali murid untuk membimbingnya.

Setelah semua soal selesai serta siswa mnejawab pertanyaannya, siswa mengatakan kepada guru dengan berlomba-lomba bahwa mereka sudah selesai mengerjakann soal. Setelah itu guru meminta siswa untuk mengucapakan jawaban mereka yang diikuti dengan menunjukannya ke kamera. Cara guru menilai hasil siswa dengan cara seperti itu. Guru menyebutkan nama dilihat dari absensinya. Siswapun sudah terlihat paham dan biasa dengan cara penilaian guru tersebut.

Semua siswa satu persatu disebutkan dan mengikuti semua prosesnya dengan baik. Salah satu siswa ketika guru sedang memberi nilai pada siswa lain, dia mengatakan kepada gurunya untuk segera membuat celengan tersebut, tampak terlihat sudah tidak sabar, sangat semangat untuk membuat proyek. Guru merespon siswa dengan ramah dan bijak. Guru memerintahkan siswa untuk mengecek kembali bahanbahan yang akan diperlukan mereka guna untuk kelangsungan mereka membuat proyek, agar terhindarnya kendala. Barang-barang tersebut berupa gunting, lem, bentuk bangun datar yang terbuat dari karton, koran, plastic atau lainnya yang mudah siswa dapatkan dan dibentuk sesuai konsep kreativitas mereka. 
Guru memerintahkan siswa untuk membuat celengannya. Gru memantau satu persatu celengan apa yang akan mereka buat. Kemudia guru mengingatkan hati-hati dan harus dipantau dan didampingi oleh wali murid dirumah juga. Siswa terlihat asik sendiri mengerjakan celengan sesuai ide kreativitas mereka. Karena waktu terbatas guru menghentikan sejenak para siswa yang sedang membuat proyek tersebut.

Project based learning memberikan kesempatan untuk mempelajari topik tertentu secara mendalam dan secara mandiri mengenai apa yang dipelajar, mempertahankan minat, serta motivasi untuk bertanggung jawab terhadap proses belajar. Project based learning memeliki beberapa karakteristik yaitu, mengajukan pertanyaan pendorong, sentralitis atau penyatuan, mengiknvestigasi secara konstruktif, paham realisme dn otonomi, pentingnya siswa berkolaborasi, merefleksi, melakukan pengulangan penyusunan, dan mempresentasikan yang ditekankan depan publik menurut Kokotsaki, dkk dalam (Guru, Menulis, and IImiah 2021).
Guru memerintahkan siswa untuk melanjutkan proyek tersebut setelah pembelajaran usai dan dengan syarat pembuattannya harus dividio dan hasilnya difotokan dengan peserta didiknya. Siswa menyimak kemudian dari beberapa siswa napak menyampaikan secara bersaama keinginan sesuai imajinasi dari kreatikvitas siswa, guru menanggapi secara positif terlihat agar siswa merasa bangga dan percaya diri apa yang akan mereka buat sehingga tidak membatasi kreativitas mereka, Guru memberi apresiasi atas apa yang ingin mereka buat.

Setelah itu guru membahas pelajaran hari ini. Menutup pembelajaran dengan salam, serta mengingatkan siswa stelah selesai proyek mereka harus langsung dikumpulkan kepada guru.

Dibawah ini merupakan hasil beberapa proyek dari siswa kelas $1 \mathrm{sd}$ Al-Imam dengan kreativitas mereka dalam membuat celengan dengan bahan dan bentuk dasar dari segiempat, segitiga serta lingkaran. Selama proses belajar-mengajar siswa sangat aktif, kolaboratif, serta memahami materi yang guru ajarkan dengan model pembelajaran project based learning, dan efektif dalam 
Didaktik : Jurnal Ilmiah PGSD STKIP Subang, ISSN Cetak : 2477-5673 ISSN Online : 2614-722X Volume 07, Nomor 01, Juni 2021

pembelajaran di masa pandemi covid19.
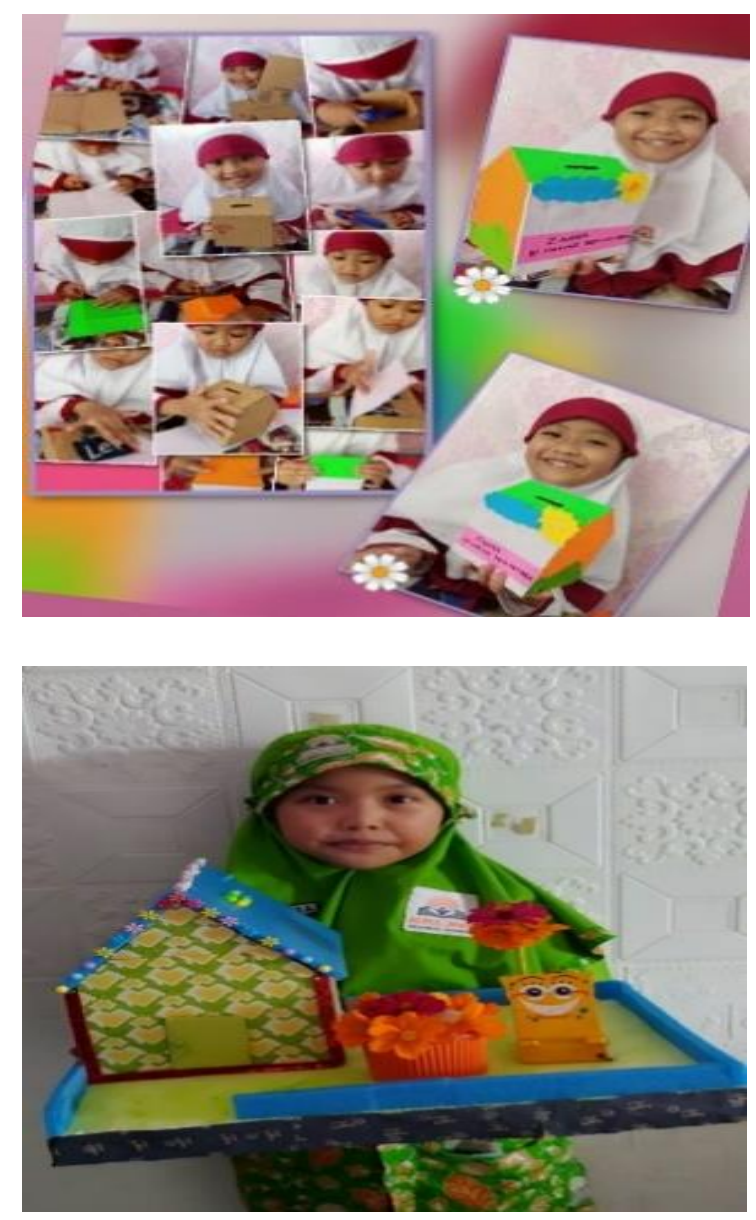

Gambar 3. Hasil proyek siswa

Hasil belajar siswa berup produk ini dinilai maksimal. Siswa mampu memhami konsep dan meningkatka pemahaman pemacahan masalah mereka, mampu mengkontruksikan dan bekerja secara nyata dan berkolabortif dengan teman-temannya saat proses pembelajaran dan perbnicangan secara online pribadi dari proyek mereka yang dibuat.

\section{E. Kesimpulan}

Siswa kelas 1 sekolah dasar SD Al-Imam dalam pembelajaran matematika dengan materi bentuk dasar bangun datar menggunakan Model pembelajaran project based learning di masa pandemi covid-19 mendapatkan hasil baik. Model pembelajaran project based learning bisa menjadi salah satu solusi model pembealajaran di masa covid-19. Siswa dengan aktif, kolaboratif dapat menyelesaikan permasalah dengan ide kreatif mereka dan tujuan pembelajaran tercapai. Selama proses pembeajaran berlangsung terdapat beberapa kendala yang dirasakan siswa, guru ataupun orang tua siswa (Di and Pandemi 2020). Terkendalanya jaringan internet, dan kuota menjadi kendala utama, Namun atas kendala tersebut guru memberikan solusi dengan merekam selama proses pembelajaran dan membuka diskusi secara pribadi dengan waktu 24jam terkait segala sesuatu mengenai tugas, pembelajaran dan lain sebagainya yang menyangkut tugas siswa.

Seperti yang dikemukakan (Dahlan et al. 2020) Penggunaan model pebelajara project based learning membuat siswa berinteraksi 
Didaktik : Jurnal IImiah PGSD STKIP Subang,

dan menggabungkan ide-ide yang ada pada dalam diri siswa untuk menyelesaikan permasalahan dengan proses mengumpulkan in formasi dan menyelidiki hingga dihasilkannya suatu produk yang dapat bermanfaat bagi siswa. Dengan model pemelajaran project based learning siswa menjadi lebih aktif dalam proses pembelajaran, karena adanya peningkatan motivasi siswa dari beberapa pertanyaan guru yang membuat siswa tertantang berusaha mencari jawabannya menurut (Salmi, Azis, and Patandean 2017). Selain itu, model pembelajaran ini juga memotivasi siswa untuk merefleksi apa yang dipelajari dalam bentuk produk hasil yang mereka lakukan sendiri secara realistis. Sehingga pada akhirnya model pembelajaran project based learning memaksimalkan proses belajar mengajar dan tujuan pembelajaran tercapai.

\section{DAFTAR PUSTAKA}

Anon. 2020. "Кинетика Реакций 1- И

2-Нафтила C

Метилацетиленом И 1,2-

Пропадиеном." Краткие Сообщения По Физике Физического Института Им. П.Н. Лебедева Российской Академии Наук 47(3).
Besare, Stefen. 2020. "Hubungan Minat Dengan Aktivitas Belajar Siswa." JINOTEP (Jurnal Inovasi Dan Teknologi Pembelajaran): Kajian Dan Riset Dalam Teknologi Pembelajaran 7(1):1825. doi: 10.17977/um031v7i12020p018.

Covid-, Tengah Wabah. 2020. "1 , 2 1,2." VI:296-304.

Dahlan, Taufiqulloh, Dadang Iskandar, Deni Harmaen, and Hani Noerafifah. 2020. "Analisis Kerja Sama Siswa Sekolah Dasar Melalui Pembelajaran Project Based Learning." Didaktik : Jurnal IImiah PGSD STKIP Subang 6(2):234-43. doi: 10.36989/didaktik.v6i2.142.

Di, Rumah, and Masa Pandemi. 2020. "1 , 2 1,2." V.

Guru, Kompetensi, Dalam Menulis, and Karya IImiah. 2021. "ONLINE PROJECT BASED LEARNING DALAM MENINGKATKAN ELSE ( Elementary School Education Journal )." 5:1-10.

Iryanti, Veronica Eny, Wahyu Lestari, and Moh. Hasan Bisri. 2021.

"Textual Study of Sandul Performance Candigaron Village Sumowono District Semarang Regency." SSRN Electronic Journal. doi: 10.2139/ssrn.3800633.

Kusuma, I. Gusti Ayu Jayanti. 2018. "Penerapan Model PJBL Berbantuan Media Audiovisual Untuk Meningkatkan Hasil Belajar IPA Siswa Kelas V SD." Jurnal Ilmiah Pendidikan Profesi Guru 1(1):29-38.

Lestari, Wahyu, Loviga Denny

Pratama, and Wahyu Hidayatillah. 2020. "Persepsi Guru Dan Siswa Tentang Penggunaan Media Edutainment Di Tengah Pandemi Covid-19." 
Didaktik : Jurnal IImiah PGSD STKIP Subang,

Jurnal Pendidikan Matematika RAFA 6(2):109-22.

Lukman, Annisa Fitria. 2020. "Penggunaan Model Blended Poe2We Untuk Remediasi Miskonsepsi Pembelajaran Fisika Termodinamika." doi: 10.31219/osf.io/yghsw.

Nugraha, Trisna, Ulfah Samrotul

Fuadah, and Adila Amalia. 2020. "Indonesian Journal of Primary Education Aplikasi Discovery Learning Menggunakan Tali ( Track A Line Idea) Untuk Mendeteksi Keterampilan Berpikir Kritis Siswa Kelas VI SD." Indonesian Journal of Primary Education 4(2):9-17. doi:

https://doi.org/10.17509/ijpe.v4i2. 25087.

Rati, Ni Wayan, Nyoman

Kusmaryatni, and Nyoman

Rediani. 2017. "Model

Pembelajaran Berbasis Proyek, Kreativitas Dan Hasil Belajar Mahasiswa." JPI : Jurnal Pendidikan Indonesia 6(1):6071.

Rojabiyah, Asiah Badriyatur, and Wahyu Setiawan. 2015.

"Pembelajaran Matematik Materi Aljabar." Journal On Education 01(02):458-64.

Salmi, Novita, Aisyah Azis, and A. .. Patandean. 2017. "Penerapan Model Pembelajaran Berbasis Proyek Terhadap Motivasi Belajar Fisika Dan Keterampian Proses Sains Peserta Didik SMAN 4 Makassar." Jurnal Sains Dan Pendidikan Fisika 13(3):238-47.

Sugiyono. 2016. Metode Penelitian, Kuntitatif, Kualitatif Dan R\&D. Bandung: Alfabeta.

Untari, E., N. Rohmah, and D. W. Lestari. 2018. "Model

Pembelajaran Problem Based
Learning (Pbl) Sebagai

Pembiasaan Higher Order

Thinking Skills (Hots) Pada

Pembelajaran Ipa ...." Prosiding

SNPS (Seminar ... 135-42. 